\author{
ПРОСВЕТИТЕЛИ АЗЕРБАЙДЖАНА О РЕЛИГИОЗНОМ ВОСПИТАНИИ \\ В НАЧАЛЕ ХХ ВЕКА
}

ПРОСВІТИТЕЛІ АЗЕРБАЙДЖАНУ ПРО РЕЛІГІЙНЕ ВИХОВАННЯ HА ПОЧАТКУ XX СТ.

\title{
ENLIGHTENERS OF AZERBAIJAN ABOUT RELIGIOUS EDUCATION AT THE BEGINNING OF THE TWENTIETH CENTURY
}

$B$ начале XX века азербайджанские интеллигенты $\quad$ с демократическим мышлением выступили против традичионного, то есть устаревшего религиозного образования. Они сражались за прозрачность религиозного воспитания, за построение новой системы. Основа этой борьбы была заложена в середине XIX столетия. В статье мы постарались обобщить данные суждения и выявить основную суть проводимой борьбы. В процессе исследований мы ссылались на мнения ведущих представителей интеллигенции Азербайджана, сыгравщих огромную роль в общественнопедагогической жизни тогдашнего времени. Среди них можно указать А. Агаоглу, А. Гусейнзаде, М.А. Расулзаде, Н. Нариманов, Дж. Мамедгулузаде, О.Ф. Неманзаде и т.д. Можно привести много примеров из произведений, написанных хоть в педагоги ческом, хоть в публицистическом, хоть в художественном стиле, о негативном отношении $к$ плохим духовным лицам передовых мыслителей с демократическими взглядами того времени, которые мы взяли как объект темы. Все эти мысли в обобщенной, достоверной, научной и всесторонней форме нашли свое отражение в произведении А. Агаева «Ислам, Ахунд и Хатифуулгейб». Поэтому мы довольствуемся короткой остановкой на нем. Это произведение, напечатанное в форме отдельной книги в Баку в 1904 году в типографиии «Каспи», носит художественнофрилософрский, религиозно-педагогический характер. Здесь три символических образа человека: Ислам, Ахунд и Хатифрулгейб. Ислам представляет слабого, в лохмотьях, убогой внешности исламскую религию, Ахунд представляет живое мировыми прихотями, лжеца, фральсифрикатора, консерватора, стяжателя духовного лица, а Хатифрулгейб представляет образ справедливого суда. Произведение построено в форорме диалога и спора Ислама с Ахундом, а Хатифрулгейб в нужные моменты вмешивается в разговор как судья. Ислам задает вопросы Ахундов из Корана, религии, шариата, хадисов, мировых работ. А Ахунд отвечает на эти вопросы со своей ограниченной, тщеславной, корыстной точки зрения. Вопросы религиозного воспитания занимают огромное место в творчестве Азербайджанских просветителей с демократическими воззрениями начала XX века. Они, наряду с умственным воспитанием, особое внимание обращали и на религиозное воспитание в здоровом духе подрастающего поколения.
Ключевые слова: $X X$ век, сочиальнопедагогические идеи, воспитатели, религиозное образование, просвещение азербайджанцев.

На початку XX століття азербайджанські інтелігенти з демократичним мисленням виступили проти традиційної, тобто застарілої релігійної освіти. Вони боролися за прозорість релігійного виховання, за побудову нової системи. Основа цієї боротьби була закладена в середині XIX століття. У статті ми намагалися узагальнити дані судження, а також виявити основну суть проведеної боротьби. у процесі досліджень ми посилалися на думки провідних представників інтелігенції Азербайджану, які зіграли величезну роль у суспільно-педагогічному житті тодішнього часу. Серед них можна вказати А. Агаоглу, А. Гусейнзаде, М.А. Расулзаде, Н. Наріманов, Дж. Мамедгулузаде, О.Ф. Неманзаде та інших. Можна навести чимало прикладів з творів, написаних хоч у педагогічному, хоч у публіцистичному, хоч у художньому стилі, про негативне став лення до поганих духовних осіб передових мислителів з демократичними поглядами того часу, які ми взяли як об'єкт теми. Всі чі думки в узагальненій, достовірній, науковій та всебічній формі знайшли своє відображення в творі А. Агаєва «Іслам, Ахунд і Хатіфрулгейб». Тому ми задовольнимося короткою зупинкою на ньому. Це твір, надрукований у формі окремої книги в Баку в 1904 рочі в друкарні «Каспі», має художньо-срілософрський, релігійно-педагогічний характер. Тут три символічних образи людини: Іслам, Ахунд і Хатіфуулгейб. Іслам являє слабку, в лахмітmі, убогої зовнішності ісламську релігію, Ахунд представляє живе світовими примхами, брехуна, фральсифрікатора, консерватора, користолюбця духовної особи, а Хатісрулгейб представляє образ справедливого судді. Твір побудований у фрормі діалогу і суперечки Ісламу з Ахундов, а Хатіфрулгейб в потрібні моменти втручається в розмову як суддя. Іслам ставить запитання Ахундов з Корану, релігії, шаріату, хадисів, світових робіт. Ахунд відповідає на ці питання зі своєї обмеженої, пихатої, корисливої точки зору. Питання релігійного виховання займають велике місче в творчості Азербайджанських просвітителів з демократичними поглядами початку XX століття. Вони, поряд з розумовим вихованням, особливу увагу приділяли і релігійному вихованню в здоровому дусі підростаючого покоління.
Азербайджанского государственного

педагогического университета 
Ключові слова: $X X$ століття, соціальнопедагогічні ідеї, вихователі, релігійну освіту, просвітництво азербайджанців.

At the beginning of the twentieth century Azerbaijani intellectuals with democratic thinking opposed traditional, that is, outdated religious enlightenment. They fought for the transparency of religious education, for the construction of a new system. The foundation of this struggle was laid in the middle of the 19th century. In the article, we tried to summarize these judgments, as well as to identify the main essence of the ongoing struggle. In the process of research, we referred to the opinions of the leading representatives of the intelligentsia of Azerbaijan, who played a huge role in the social and pedagogical life of that time. Among them are A. Agaoglu, A. Huseynzade, M.A. Rasulzade, N. Narimanov, J. Mammadguluzade, O.F. Nemanzade, etc. There are enough examples from works written in pedagogical, even in journalistic, even in artistic style, about the negative attitude towards bad clergy of progressive thinkers with democratic views of the time, which we took as the object of the topic. All these thoughts in a generalized, reliable, scientific and comprehensive form were reflected in the work of $A$. Agayev "Islam,
Akhund and Khatifulgeib". Therefore, we will be content with a brief stop on it. This work, printed in the form of a separate book in Baku in 1904 in the "Kaspi" printing house, has an artistic, philosophical, religious and pedagogical character. There are three symbolic images of a person: Islam, Akhund and Khatifulgheib. Islam represents a weak in rags, shabby appearance, the Islamic religion, Akhund represents a liar, a falsifier, a conservative, a self-interested clergyman living on world whims, and Khatifulgeib represents the image of a just judge. The work is built in the form of a dialogue and dispute between Islam and Akhund, and Khatifulgeyb intervenes in the conversation as a judge at the right moments. Islam asks questions to Akhund from the Koran, religion, Sharia, hadith, world works. And Akhund answers these questions from his own limited, vain, selfish point of view. The issues of religious education occupy an important place in the work of Azerbaijani educators with democratic views at the beginning of the 20th century. They, along with mental education, paid special attention to religious education in the sound spirit of the younger generation.

Key words: $X X$ century, social and pedagogical ideas, educators, religious education, enlightenment of Azerbaijanis.
Постановка проблемы в общем виде. Вопросы религиозного воспитания занимают большое место в творчестве Азербайджанских просветителей с демократическими взглядами начала XX века. Они, наряду с умственным воспитанием, особое внимание уделяли и религиозному воспитанию в здравом духе подрастающего поколения. Изучение и применение в школьной практике этих вопросов в наше время приобретает актуальность.

Впервые в сравнительной фрорме исследуются и анализируются вопросы религиозного воспитания в творчестве Азербайджанских просветителей с демократическими взглядами начала $\mathrm{XX}$ века.

Мысли о религиозном воспитании Азербайджанских просветителей с демократическими взглядами начала $\mathrm{XX}$ века могут использоваться в обучении и воспитании подрастающего поколения.

Изложение основного материала. В начале XX века в общественно-культурной жизни, особенно в период Первой русской революции (1905-1907), проблема проведения серьезных ресрорм в духовных учреждениях стала более актуальной. Национальные воспитатели, которые смотрели на духовные учреждения как на очаги национального воспитания, воспитательные структуры, выступили против их деятельности на основе традиционных законов. Ахмед бек Агаев предложил провести меджлис в городе Гянджа с участием интеллигенции и представителей народа, пригласить туда и влиятельные духовные лица. В меджлисе обсуждать необходимые для воплощения в жизнь ресрормы в национальных духовных учреждениях. А. Агаев особенно оста- навливался на вопросе, чтобы и председатели (руководители), и члены в духовные учреждения назначались не правящими кругами, а избирались народом. Только избранные народом духовные лица могут принести пользу народу, стараться для его прогресса. В 1906 году это предложение заинтересовало широкую массу интеллигенции и стало объектом дискуссий. О.Ф. Неманзаде в своей статье «В чем наше спасение?» («Иршад», 1906, 9 октября) выражает свое отношение к этому предложению, согласуется с мыслями Ахмед бека. Он доводит до сведения, что прогресс некоторых народов, в том числе европейцев, стал возможным после потери духовными лицами силы и авторитета. Лишить авторитета, отстранить от общественно-культурных и воспитательных процессов духовные учреждения, которые являются нашими единственными национальными организациями, в данной исторической обстановке невозможно. Вместе с тем, надо срочно решать одну важную проблему. А это «реформа наших духовных учреждений». Потому что «наши духовные учреждения вместо того, чтобы вывести нас к прогрессу, сегодня стали для нас большой бедой и оковами, стали преградой на пути прогресса, просветления, освобождения [7, с. 142]. Автор выступает против назначения руководителей духовных учреждений политическими властями, защищает предложение А. Агаева об их избрании народом. Добавим и то, что когда воспитание нашего «тела и духа» «в руках духовных учреждений», одним из важных вопросов является открытие религиозных школ нового типа, нового духа, соответствующих требованиям 
времени, проведение в старых школах рефрорм и приспосабливание в них учебы и воспитания к требованиям времени. По решению автора, если «духовные руководители маленьких народов, которые в подчинении большого государства, не подчиняются этому народу, то этот народ не сможет сохранить свое существование» [7, с. 145].

Омар Фаиг в своей статье «Наш свет не погаснет» («Ачыг соз», 1916, № 90), излагая свои суждения о восхождении народа, говорит, что прогресс и эволюция однозначно зависит от двух условий: или религиозных, или политических перемен. Несмотря на то, что эти перемены и революции связаны с общественно-политической и культурной обстановкой в стране, более или менее различаются по природе и нравственности народов, в конечном счете все одинаковы [7, с. 249].

И.У. Гаджибеков в фрельетоне «Насущные вопросы и важные ответы» («Иршад», 1907, 17 апреля) критиковал назначение руководителей духовных учреждений, являющимися очагами нравственного воспитания народа, официальными государственными органами. Один из национальных воспитателей А. Гусейнзаде хвалил ислам как одну из современных систем убеждения, имеющего высокое человеческие ценности, старался объяснять массе его красоту, превосходящие черты. Известно, что второй из трех элементов (тюркство, ислам, западничество) его национально-идеологической концепции является ислам. Выдвинутая им теоретико-идеологическая концепция скоро сорормировалась в виде «тюркизироваться, исламизироваться, модернизоваться» и встала в центре нашей государственной идеологии. «Фюузат»цы были сторонниками здорового религиозного воспитания и старались превратить его на практическую деятельность, на практическую работу каждого ради общества и человечности. «Известный религиозный деятель Магомед Убейдулла бек в своей статье «Мусульманство», напечатанной в 30-ом номере от 1907 года журнала, поясняет, что мусульманство состоит не только из веры и богослужения. Настоящие критерии его, в первую очередь, деяния, проделанные работы. От несоответствующего настоящим правилам, здравым, научным и шариатским велениям практического ислама человек не может считаться мусульманином. Приносить пользу братьям по религии, всему человечеству является долгом настоящего мусульманина [3, с. 472].

Отношение к религии и вопросы религиозного воспитания занимают большое место в творчестве М.А. Расулзаде. Он в своих статьях коснулся этих вопросов, выдвигал важные суждения. Из этих статей можно показать нижеследующие: «Сегодня» («Иршад», 1906, 4 сентября); «Национальное возрождение» («Возрождение»,
1914, № 1-7); «Совет просвещения» («Открытое слово», 1916, 7 апреля); «Школа и медресе» ((«Открытое слово», 1916, 15, 16, 17, 21, 27, 31 марта, 4 апреля, 2, 6, 7, 10 июня); «Праздник одного медресе» («Открытое слово», 1916, 28 декабря); «Ислам и родной язык» («Открытое слово»,1917, 27, 28 фревраля)).

По мнению М.А. Расулзаде, религиозное воспитание является важным условием для прозрения общественного существа, нравственной эволюции. Первобытный человек, познавая себя и окружающих, овладел «национальным чувством», желанием познания окружающего мира «поверив одной силе мудрости» овладел «религиозным чувством». Эти два чувства тесно связаны между собой. И еще «так как религиозное чувство является целью национального чувства, отношение между национальным и религиозным положением бывает постоянно» $[10$, c. 353].

В статье «Национальное возрождение», напечатанной в 1914 году в журнале «Возрождение», М.А. Расулзаде обстоятельно говорит об основных атрибутах, определяющих национальное существо народа, дает их научное разъяснение. И считает необходимым построение системы воспитания народа в соответствии гармонии, защиты этих атрибутов. Нижеследующих он считает этими атрибутами: 1.Национальное обожание; 2. Национальная вера и совесть; 3. Национальный идеал; 4. Национальный язык и отношение к нему; 5. Религия; 6. Национальная традиция.

Как видно, закрепляется, что одним из атрибутов, определяющее национальное существование, является религия. Автор историческими фактами доказывает, что религия и национальное существование тесно связаны между собой. И часто помогает народу защищать свое национальное существование и достоинство. Например, причиной неподтверждения ассимиляции армян среди мусульман, татар среди христиан является религия.

М.А. Расулзаде всесторонне и логично излагает еще один актуальный вопрос, который является очень важным для религиозного воспитания. Показывает, что священная книга Коран ислама, которая зарождалась в арабской сфрере, различные ритуалы, молитвы и слова богослужения на арабском языке. К сожалению, ни один из них не переводился на язык, принявших ислам. И турки, и персы, и немусульмани часто не понимают значение ни читаемых из Корана, ни читаемых на арабском языке молитв. Из немусульман понимали это только получившие образование на арабском языке. Поэтому результаты досадные. Между многочисленной толпы, непонимающегозначениеуслышанного ипроизнесенного, и услышанного, произнесенного образовалась занавесь франатизма, а это открыло путь 
к франатизму, суеверию, невежеству. В результате, народам, наряду с приобретением из религии, и приходится потерять многое: «Вот использование представления по-арабски принадлежность исламских ритуалов и Корана арабскому языку привело к потере в исламской морали и нравственности. С этой точки зрения потерю в культуре неарабских народов, подчиняющихся исламу, не сосчитать.

Если религия и ее цели не понятны ее служителям, то она не сможет обеспечить свою пользу, будет бездушным, отдалится от быта...» [9, с. 48]. Поэтому М.А. Расулзаде, как один из теоретиков национального воспитания с национальными взглядами, перевод Корана и других важных молитв на национальный язык, ведение религиозного воспитания на национальном языке считал необходимым. Объясняет и то, что религия опирается на интернационализм, а язык на национализм. Учитывая это, надо объяснять народу схожие и различные черты «мусульманства» и «национализма». Такое просветление должно стать необходимым элементом религиозно-воспитательной миссии.

Известный педагог Г.Р. Мирзазаде в своем произведении «Ритуалы народа. Проснитесь, братья!», которое напечаталось в виде отдельной книги в 1908 году, передает свои суждения о причинах отсталости, регрессии народа, а также предстоящих делах для прогресса и воспитания народа, о путях выхода из этого положения. Надо коснуться еще одной проблемы, говоря о развитии теории религиозного воспитания в период национального возрождения. В исследованиях, связанных с теоретиками воспитания, творческого наследия элиты интеллигенции того времени, в советское время проявила себя такая ошибочная, необъективная тенденция. В творчестве обладателей пера и мысли с национальными идеями того времени искались идеи «атеизма, безбожника, отвращения к религии». Их отношение к исламу и вообще к религиям излагается неправильно, односторонне. Исследователи, как правило, не выступали из фрактов, склонялись к тотальному «поиску атеизма» в наследии этих личностей. Как говорится в одном учебном пособии о теории воспитания, в советское время: «Религия - опиум для народа», «Религия франтастическое отражение внешних сил в уме», подходя ряду таких мыслей безоговорочно, будто религия «носит абсолютно реакционный характер; она совокупность мистических взглядов, основывающих на веру в бога, духов и другим воображаемым силам» поэтому не сыграла никакую положительную роль в жизни человека, народа, общества; будто в религиозном обучении, ритуалах, традициях, в религиозных книгах нет ничего умного, полезного и т.д.»
[4, с. 65]. Конечно, такая ошибка питалась от господствующей идеологии большевизма. Исследования, которые велись под диктовкой господствующей модели идеологического отрицания в отношении религиозного убеждения советского режима, привели к довольным недостаткам в научных изложениях и анализах. Тогда, как большинство наших демократических интеллигентов, живших в пределах XIX-XX столетий, с любовью и симпатией относились к исламу, и к другим классическим религиям. Они плохо относились не к самой религии и к их атрибутам, критиковали не сами религии, их атрибуты, а религиозных, консервативных религиозных деятелей. В конечном результате в период советского империализма отношения к религии и религиозным деятелям отождествлялись, понятие «плохой религиозный деятель» представлялся в смысле «религия плохая и ненужная». Такая тенденция привела к ненаучному, необъективному изложению религиозного воспитания в культурно-педагогической реальности Азербайджана в период национального возрождения. В период нынешнего суверенитета исправление этой ошибки является важной задачей наших исследователей.

Как и сказали, во второй половине XIX века и начале $X X$ века ведущие демократические мыслители Азербайджана плохо относились и серьезно критиковали корыстолюбивые, реакционные, консервативные духовные лица. Различие в мнениях между демократическими мыслителями и духовными лицами привело к серьезным конфрликтам, к ссоре мыслей и слов, к столкновению идей. Г. Зардаби в статье «Объединение языка» («Жизнь», 1906, 11 января) говорит, что некоторые моллы и деятели печати портят язык, говорят и пишут на непонятном языке. Отмечает, что язык наших корреспондентов и духовных лиц ни тюркский, ни другой язык. Этот язык смесь нескольких языков. С.А. Ширвани в сатирах «Необразованный ученый», «Поминальный обед собаке», в некоторых просветительских стихотворениях из цикла «Наставления сыну» критикует поддельные, неграмотные, корыстные религиозные деятели. Доводит до сведения, что их слова ложные, их воспитание бесполезное.

По решению М.Шахтахтлы, два фрактора, мешающие прогрессу народа, в передней позиции и опасны. Один из них основывается на монорхизме, деспотизме, а второй на господстве духовных лиц, которое является нравственно-идеологической опорой абсолютного и чрезмерного господства первого. Европейцы, сокрушая господство духовных лиц в общественной жизни, разбили и оковы деспотизма. С этим открыли новые двери для воспитания и прогресса. Но продолжается господство мусуль- 
манских духовных лиц, и они не считают людей достойными «к закону свободного выбора для использования своего ума, различать хорошее от плохого» [11, с. 44].

В одной из статей из цикла «Каждый день немножко», напечатанной под псевдонимом «Газетнавис» в газете «Восточный рус» (1904, 30 июня), М. Шахтахтлы на примере одного моллы рассказывает о лживости моллы, о посягательстве моллы на вымышленные слова, даже о пророке, ради своих интересов и прибыли.

Н. Нариманов, как и М. Шахтахтлы, в рассказе «Святыня» показывает настоящее лицо религиозных деятелей. В своих статях из цикла «Вопль недели», печатающиеся в газете «Жизнь», воспитатель-деятель обвиняет духовные лица в препятствии развитию народа, в неспособности оказания должной службы народу, в непонимании духа времени, в не в обучении подрастающего поколения чемунибудь полезному в учебно-воспитательной деятельности [8, с. 258].

Обвиняет духовные лица, которые столетиями держали ислам в темноте, не давали исламскому миру развиваться, в историческом преступлении. Обращаясь к ним, говорит: «Нет, господа покровители ислама! Вы совмещались временем, вы столетиями держали ислам в темноте, вы не могли похоронить исламскую свободу...» [8, с. 247].

М.А. Сабир, как и его сослуживец Мирза Джалил, в своих сатирах преследует цель ознакомить массу с личностью и деяниями религиозных деятелей.

Выводы. Можно привести достаточно примеров из произведений, написанных хоть в педагогическом, хоть в публицистическом, хоть в художественном стиле, о негативном отношении к плохим духовным лицам передовых мыслителей с демократическими взглядами того времени, которые мы взяли как объект темы. Все эти мысли в обобщенной, достоверной, научной и всесторонней форме нашли свое отражение в произведении А. Агаева «Ислам, Ахунд и Хатифулгейб». Поэтому мы удовлетворимся краткой остановкой на нем. Это произведение, напечатанное в фрорме отдельной книги в Баку в 1904 году в типографии «Каспи», носит художественно-философрский, религиозно-педагогический характер. Здесь три символических образов человека: Ислам, Ахунд и Хатифрулгейб. Ислам представляет слабого, в лохмотьях, убогой внешности исламскую религию, Ахунд представляет живущую мировыми прихотями, лгуна, фральсифрикатора, консерватора, корыстолюбца духовного лица, а Хатифулгейб представляет образ справедливого суди. Произведение построено в форое диалога и спора Ислама с Ахундом, а Хатифулгейб в нужные моменты вмешивается в разговор как судья. Ислам задает вопросы Ахунду из Корана, религии, шариата, хадисов, мировых работ. А Ахунд отвечает на эти вопросы из своей ограниченной, тщеславной, корыстной точки зрения. Выясняется, что он читает Коран, но не повинуется. Читает фальшивые проповеди, но занимается недостойными делами. Стишки Корана, законы шариата доводит до народа по-своему. В религии дает ход расколу, секте, внутренней вражде. Не ведает о внутренних правдах, двигается только внешними правдами. В произведении на каждом шагу Ислам обвиняет Ахунда. Доводит до сведения, что по вине религиозных деятелей народ отдаляется от Ислама, остается неосведомленным о настоящей божественной науке, о настоящих шариатских законах.

\section{БИБЛИОГРАФИЧЕСКИЙ СПИСОК:}

1. Агаоглу А. (2007). Избранные произведения. Баку.

2. Газета «Экинчи». (1875-1877) (1979). Баку.

3. Журнал «Фуюзат» (1906-1907) (2007). Баку.

4. Гашимов А., Садыгов Ф. (1995). Педагогика. Баку.

5. Гусейнзаде А. (2007). Избранные произведения. Баку.

6. Мирзазаде Г. Р. (1908). Ритуалы народа. Проснитесь братья. Баку.

7. Неманзаде О. Ф. (1992). Избранные произведения. Баку.

8. Нариманов Н. (1973). Избранные произведения. Баку.

9. Расулзаде М. А. (2001). Произведения. II т. (1909-1914). Баку.

10. Расулзаде М. А. (2013). Произведения. IV т. (1917-1918). Баку.

11. Шахтахтлы М. (2006). Избранные произведения. Баку. 